\title{
The Adoption of Blended Learning in Non-Formal Education Using Extended Technology Acceptance Model
}

\author{
R Kurniawan *1, Pramana ${ }^{2}$, Budianto ${ }^{3}$ \\ ${ }^{1}$ Institut Sains dan Teknologi Terpadu Surabaya, Indonesia \\ ${ }^{2}$ Assumption University, Bangkok, Thailand \\ ${ }^{3}$ Institut Sains dan Teknologi Terpadu Surabaya, Indonesia \\ E-mail: ridhokurniawan14@gmail.com¹,epramana@stts.edu², \\ herman.budianto@gmail.com ${ }^{3}$
}

Submitted: 21 May 2021, revised: 22 July 2021, accepted: 26 July 2021

\begin{abstract}
Abstrak. Penelitian ini bertujuan untuk mengetahui faktor-faktor yang mempengaruhi pemahaman niat peserta didik pada pendidikan non-formal dalam menggunakan blended learning dan mengetahui hubungan faktor-faktor dalam model teoritis. Penelitian ini dilakukan karena masih minimnya penelitian di dunia yang membahas tentang penerapan blended learning pada pendidikan non-formal di negara berkembang seperti Indonesia. Blended Learning pada pendidikan non-formal di masa pandemi Covid-19 diperlukan karena institusi pendidikan memiliki keterbatasan tempat untuk menampung peserta didik. Kuesioner yand dibagikan melalui Google Form digunakan untuk mengumpulkan data. Sampel merupakan 566 pengguna blended learning dari lembaga pendidikan non-formal di Indonesia. Semua variabel dari model teoritis diukur dengan menggunakan skala yang ada. Structural Equation Model (SEM) digunakan untuk menganalisis model teoritis. SPSS dan Amos digunakan sebagai perangkat lunak pendukung analisis. Penelitian ini berkontribusi pada pemahaman teoritis adopsi Blended Learning serta praktik dan panduan bagi Pendidikan Non-Formal agar berhasil menerapkan Blended Learning di institusinya. Dari tiga belas hipotesis awal, terdapat sembilan hipotesis yang signifikan. Tiga hipotesis dengan besaran terbesar adalah SI $\rightarrow$ PU, CE $\rightarrow$ PEU, dan PU $\rightarrow$ BI. SI merupakan faktor yang paling berpengaruh dalam penerapan blended learning di lembaga pendidikan nonformal.
\end{abstract}

Kata Kunci: pembelajaran campuran, SEM, TAM, pendidikan non-formal

Abstract. This study aims to determine the influencing factors for understanding the intention of the learners in non-formal education to use Blended Learning. It also aims to investigate the relationships of the factors in a theoretical model. This study was conducted due to the lack of research in the world that discusses the adoption of Blended Learning in non-formal education in developing countries such as Indonesia. Blended Learning at non-formal education in the Covid19 pandemic is needed because the education institution has a limited place to accommodate learners. A questionnaire-based on google form was distributed to 566 users of Blended Learning on non-formal education institutions in Indonesia in order to collect data. All variables from the theoretical model were measured using existing scales. Structural Equation Model (SEM) was

Kurniawan, Pramana, Budianto (The Adoption of Blended Learning in Non-Formal Education Using Extended Technology Acceptance Model) 
used to analyze the theoretical model. SPSS and Amos were used as the software tools. This research contributes to the theoretical and practical understanding of Blended Learning adoption and provides guidance for non-formal education to successfully implementing Blended Learning in the institutions. From the thirteen initial hypotheses, there were nine significant hypotheses. Three hypotheses with the largest magnitude were SI -> PU, CE -> PEU, and PU -> BI. SI was the most influencing factor in the adoption of blended learning at non-formal education institutions.

Keywords: blended learning, SEM, TAM, non-formal education

\section{Introduction}

The issue of quality of education in the outermost, frontline, and disadvantaged regions in Indonesia has become a mandatory subject of discussion for education activists. The distribution of education still becomes an agenda of sustainable development in Indonesia. Based on data from the National Development Planning Agency (Bappenas), the government sets the number of disadvantaged areas every five years. In 2015, there were 122 disadvantaged districts and 43 frontline and outermost districts. Government Regulation No. 78 of 2014 mentions that the criteria of a disadvantaged area can be seen from the human resources, facilities and infrastructures, local financial capability, accessibility, and the characteristics of the area. Non-formal education is the education outside the formal education that can be implemented in a structured and leveled model such as courses and training. Providers of non-formal education and training in developing countries also create responses that are imaginative, thoughtprovoking, and even inspiring to face the global challenges in achieving the Education for All/equal education distribution [1]. Based on data from the Ministry of Education and Culture (Kemdikbud), Indonesia has 20.530 non-formal education, and East Java Province has 2.535 institutions of non-formal education including Courses and Training Center (LKP), Community Learning Center (PKBM), and SKB. Currently, non-formal education institutions like LKP do not have a lot of enthusiasts compared to formal education. However, the intention of the learners to participate in non-formal education is very high because they want to develop their competencies to increase their employability in the industry.

Formal education, the basic education up to the higher education, in Indonesian context, requires a relatively expensive cost, and take a considerable amount of time (more than 16 years of education). Regarding the condition, people who want to prepare themselves with the skills needed to get to work with affordable cost of education tend to choose non-formal education. LKP and PKBM are classified as non-formal education institutions (PNF), which have licenses and are supported by the local Department of Education. Some teaching and learning activities conducted are still using traditional methods, and some have already applied Blended Learning. Non-formal education classes may consist of students of different ages. There are some differences between LKP and PKBM. In LKP, the learning activities are free. The students can also choose private teaching and learning activities depending on the LKP, which teaching methods the instructor would like to use. LKP provides students with a competency/skill output which is proven with a certificate of competence. Students can choose a package/program that they like. Furthermore, LKP differs from PKBM in terms of the general learning subjects that LKP does not provide general learning subjects such as Math and Science. LKP directly leads the students to the competency skills in which they are interested in. On the other hand, PKBM has similar teaching and learning activities to those in formal education, but the institution is still included in the PNF unit. PKBM handles students like those in the formal education who will receive a Package A Certificate which is equivalent to Basic Education/Elementary School (SD), a Package B Certificate which is equivalent to Secondary Education/Junior High School (SMP), and a Package C Certificate which is equivalent to a higher Secondary Education/Senior High School (SMA).

Kurniawan, Pramana, Budianto (The Adoption of Blended Learning in Non-Formal Education Using Extended Technology Acceptance Model) 
Non-formal education has similar teaching methods to formal education, such as traditional and modern learning methods using technology. The integration between adaptive technology and learning skills has emerged to transform online learning as a trend and a model in providing access to resources and information [2] and collaborative learning without any space boundaries [3]. The teaching process conducted by non-formal education institutions is chosen depending on the institutions themselves whether they prefer to use traditional or modern learning systems. Still, this study chose non-formal education institutions which used the mixed teaching and learning system or can be called blended learning. Perceptions on blended learning have become trends within the last few years [4]. Blended learning is defined as a system of learning that integrates a variety of learning delivery methods and a face-to-face class environment that is in line with e-learning [5]. A mixture of learning can be considered as an efficient learning approach in terms of the students' learning experience and students-instructors interaction, which later it will likely become a model of primary education in the future [6].

Blended Learning is needed in Indonesia because Indonesia currently has a slogan 'Indonesia Maju' (Indonesia Moving Forward). The Government of Indonesia invites all people to have technological awareness in government, health, agriculture, and education sector as the main source to form the future of the nation. The new generation shoulb be formed by manners and education given by teachers in the education units, both formal education and non-formal education. Unfortunately, there are still many educational institutions that are still in doubt in using electronic learning due to inadequate infrastructures, and reluctance to leave the printed paper as the learning media. Blended Learning could be the best solution because it combines the advantages of the current face-to-face class environment and the use of electronic media for learning. It is supposed to be a progression from traditional face-to-face classes to a pure electronic learning environment.

This study was conducted due to the lack of research in the area discussed this study, particularly, the non-formal education in developing countries such as Indonesia. This study focuses on the adoption of Blended Learning in non-formal education. Blended Learning at non-formal education in the Covid-19 condition is needed because each course institution has a limited place to accommodate more learners, so they can apply Blended Learning. It is not surprising that there are some online learning applications, so the researcher would like to know the important factors influencing the learners who had been treated using Blended Learning in non-formal education. Although there are several studies related to Blended Learning, there is nothing similar to this study, especially related to non-formal education. Although Blended Learning is increasingly popular for students in Indonesia, research that discusses the factors that affect the success of the adoption of blended learning in non-formal education institutions is very limited. The study of meta-analysis in the research of blended learning [7] showed there was a large gap in the research of blended learning between developed countries and developing countries. Indonesia is not even listed as a contributor in the research of blended learning in the meta-analysis study. It is therefore very important for this research to be done in Indonesia. As one of developing countries and the fourth most populous nation, the number of potential users who adopt blended learning can reach millions. Regarding the condition, this study would find out the learning interest and attitude of the students who had been treated using blended learning in non-formal education using Technology Acceptance Model (TAM) by considering the influence of external factors. Later, the findings of this study will allow academic institutions, especially in the executive education field, to develop more effective strategies to implement Blended Learning [8].

\section{Theoretical Framework}

This section consists of previous studies related to Blended Learning in the context of the use of the Technology Acceptance Model (TAM) for measuring the Acceptance of the Technology to analyze the theoretical model design [9][10][11][12][13][14][15][16][17][18][19]. TAM is one of the most prominent scientific models with many empirical tests showing the success of the TAM model [20]. The various 
existing studies received positive results, although several factors distinguish the results of the research. E-learning is also included in the scope of Blended Learning of this study. Previous research used TAM as the basic reference to determine the acceptance of the respondents with the technology. Thus, this study also used the same reference and was not performed outside the basis of research that had been done in the previous years. However, the previous studies conducted using the adoption of Blended Learning were not specific on the research focusing on non-formal education. Therefore, this study was taken due to the lack of research leading to the institutions.

Among the eleven studies, there are some determinant factors that are necessary for conducting research on non-formal education. From some previous studies, the researcher took some variables that are very important to be studied, including five exogenous variables and three basic variables of TAM. There are five exogenous variables with their labels: System Functionality which is labeled as SF, System Interactivity SI, Self-Efficacy SE, Computer Experience CE, and Social Influence SIC. These variables in provides the prediction of user acceptance of the previous studies on the adoption of e-learning [21]. The following description outlines the theoretical model in Figure 1.

\subsection{System Functionality}

System functionality focuses on the perceived ability from using e-learning to provide easy access to the learning media and assessment that enable students to access the learning materials, collect home assignments, and complete online tests or quizzes [13][22]. The previous studies also indicated that the system functionality significantly affects the confidence of users in various contexts related to e-learning [13][22]. It was found that the two variables of TAM (Perceived Usefulness and Perceived Ease of Use) are positively influenced by the system functionality [21]. System Functionality on Blended Learning can be beneficial for students to foster the learning interest so that the students feel that the system is easy to use and more useful.

\subsection{System Interactivity}

The key to the learning process is the interaction between the students themselves, the interaction between teachers and students, and the collaboration in the learning activities that results from those interactions. The main source of the development of e-learning has come through technologies that encourage the improvement of the students' interaction. The interaction between the students and educators can be synchronous or asynchronous. Thus, System Interactivity which is the interaction among the students, lecturers and students, and collaboration in Blended Learning [23], is expected to be one of the factors that can influence the adoption of the e-learning system by students. In the previous studies, the characteristics of the objective system had a direct impact on the perceived usefulness and perceived ease of use [24].

\subsection{Self-efficacy}

Self-efficacy is the belief of the individual in his/her ability to perform a certain behavior or a personal conviction about his/her ability to perform a specific task successfully. Self-efficacy is an important concept in the theory of social learning [25]. The previous studies had found that self-efficacy influences the behavior, the intention in trying to do something specific, and the achievement of the work result of an individual in connection with such behavior [26]. In Blended Learning, self-efficacy is defined as the students' confidence in his/her ability to carry out specific learning tasks by using offline, online, or LMS delivery methods. Students who have a strong understanding of the ability to use LMS may have a high perception of the ease of use and the usefulness, so they tend to be more enthusiastic about accepting and using the system. 


\subsection{Computer Experience}

Computer experience refers to the technical skills in computer operations and internet navigation to support the process of learning in Blended Learning [23]. The latest empirical studies showed that computer experience is positively related to computer attitude [27]. In a survey of 1.138 middle school students, Chen found that male students have a better computer experience compared to female students. They are more interested in computing and more confident in their ability to work with computers [28]. In the previous studies, female students who were asked to take computer courses showed a lower level of interest and level of confidence than those who did not take courses at the same school. In a survey of high school students, Linn did not find gender differences in the computer performance even though the experience of using computers of the male students is more than the female students [29]. In Indonesia, Computer Experience is also very influential on the Blended Learning process. The experience of students and educators using a computer can also determine the success or failure of a learning process.

\subsection{Social Influence}

Social influence is defined as a change in thoughts, feelings, attitudes, or behaviors of an individual resulting from interaction with another individual or group [30]. The social influence here is defined as the change in cognition, attitude, or behavior of a person, which comes from another person or group [31][32]. Studies about social influence are known for the demonstration and explanation of a dramatic psychological phenomenon that often occurs as a direct response to the open social strength. Some of the most memorable pictures of the field history described the participants striving to understand their circumstances and respond following their judgment to face the external pressure to do otherwise [32]. The Social Influence of a student affects learning that implements Blended Learning in Indonesia. The interest of students in Blended Learning is also due to a social influence so that social influence is also included in an important variable in this study.

\subsection{Perceived Usefulness}

What causes people to accept or reject information technology is the perceived usefulness that can affect system use [33]. Researchers call this variable as perceived usefulness. The perceived usefulness is known to be the determinant of Behavioral Intention for spreading Blended Learning. This research working on the adoption of Blended Learning suggests that individuals will receive mixed learning if they find it useful. Therefore, Perceived Usefulness is expected to be a strong factor for students to adopt Blended Learning.

\subsection{Perceived Ease Of Use}

Blended Learning users believe that a particular application is useful and at the same time believe that the system is too difficult to use. Evenmore, the performance benefits of the apps use outweigh the application's use effort. Perceived usefulness is defined here as "the degree to which a person believes that using a particular system will improve his/her job performance" [33]. A system with high perceived usefulness is a system in which users believe there is a positive use-performance relationship. Perceived ease of use, in contrast, refers to the degree to which a person believes that using a particular system will be effortless. It follows the definition of convenience that means free from difficulties or great effort. Researchers claim that Blended Learning is considered easier to use than other approach so that it is used as an important variable that students may accept.

\subsection{Behavioral Intention}

Behavioral intention is the main acceptance factor for users in using behavior [34]. In Blended Learning adoption research, this measures the commitment of individuals to take advantage of blended learning if it is still available to them as an option in the future. This study uses the Behavioral Intention variable as a 
measure of the interest in receiving students so that this variable is the most important and becomes the basis for previous research and as a basic model for TAM [33][35].

Figure 1 presents the theoretical model proposed in this study which consists of 5 exogenous variables and three basic variables of TAM. The theoretical model is derived from the results of previous studies.

The Theoretical Model depicted in Figure 1 was taken from the basic model of TAM [33]. In order to determine the success of the adoption of Blended Learning in the learning process in non-formal education institutions, a hypothesis model was made by using the basic constructs of TAM and some external factors. Selected external factors refer to several studies that have been described in Table 4. The common similarity is that the five external factors were often used in the above studies, and they often appeared in some existing research. The external factors/exogenous variables are System Functionality, System Interactivity, Self-Efficacy, Computer Experience, and Social Influence. Those external factors affect the intention of a person to use Blended Learning. The research conducted above provided external factors, and some of the conclusions had affected different results from one study to the other. With this research, it is expected that the researcher can provide more significant and valuable evidence for further studies.

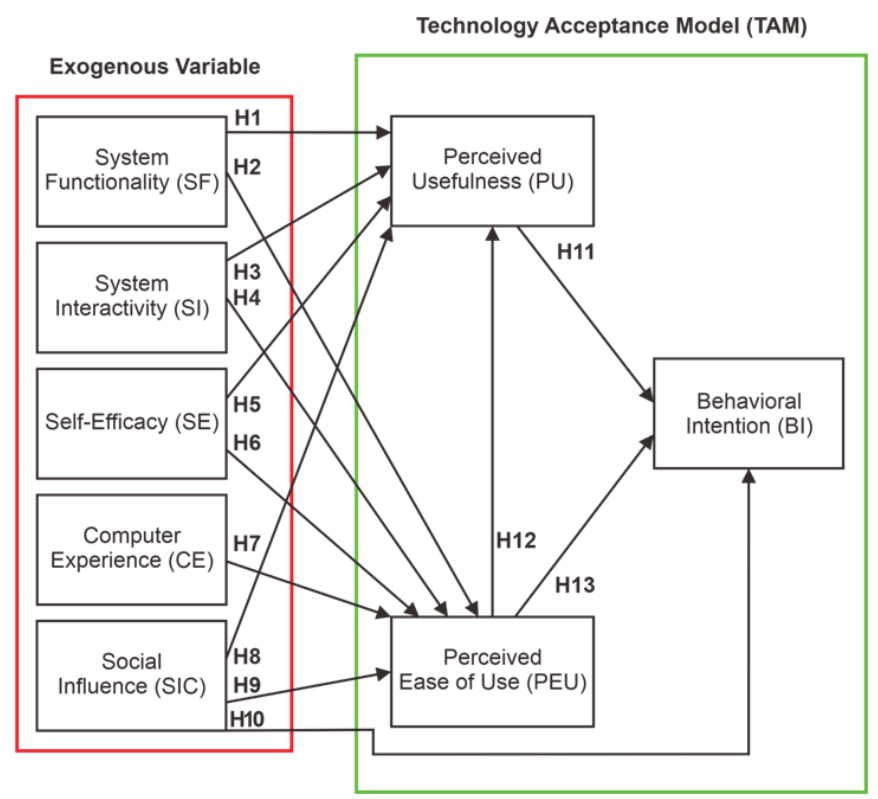

Figure 1. Theoretical Model

Figure 1 shows determinant factors that are related between one variable to the other so that the theoretical model has 13 Hypothesis Formulations which are supported by reference of previous research as described in Table 1 below:

Table 1. The Formulations of Hypothesis

\section{Hypothesis}

\begin{tabular}{llc}
\hline H1 & System Functionality has a positive and significant direct effect on Perceived Usefulness & SF $\rightarrow$ PU \\
H2 & System Functionality has a positive and significant direct effect on Perceived Ease of Use & SF $\rightarrow$ PEU \\
H3 & System Interactivity has a positive and significant direct effect on Perceived Usefulness & SI $\rightarrow$ PU \\
H4 & System Interactivity has a positive and significant direct effect on Perceived Ease of Use & SI $\rightarrow$ PEU
\end{tabular}




\begin{tabular}{llc}
\hline \multicolumn{1}{c}{ Hypothesis } \\
\hline H5 & Self-Efficacy has a positive and significant direct effect on Perceived Usefulness & SE $\rightarrow$ PU \\
H6 & Self-Efficacy has a positive and significant direct effect on Perceived Ease of Use & SE $\rightarrow$ PEU \\
H7 & Computer Experience has a positive and significant direct effect on Perceived Ease of Use & CE $\rightarrow$ PEU \\
H8 & Social Influence has a positive and significant direct effect on Perceived Usefulness & SIC $\rightarrow$ PU \\
H9 & Social Influence has a positive and significant direct effect on Perceived Ease of Use & SIC $\rightarrow$ PEU \\
H10 & Social Influence has a positive and significant direct effect on Behavioral Intention & SIC $\rightarrow$ BI \\
H11 & Perceived Usefulness has a positive and significant direct effect on Behavioral Intention & PU $\rightarrow$ BI \\
H12 & Perceived Ease to Use has a positive and significant direct effect on Perceived Usefulness & PEU $\rightarrow$ PU \\
H13 & Perceived Ease to Use has a positive and significant direct effect on Behavioral Intention & PEU $\rightarrow$ BI \\
\hline
\end{tabular}

In all hypotheses in Table 1, the term "significant" refers to the significant statistics on the level of 0.05 or less.

\section{Methodology}

This study used Structural Equation Modeling (SEM), which is a technique of statistical analysis that is both cross-sectional and commonly used for the analysis of a theoretical model. Hypotheses testing was conducted using a questionnaire to measure each of the variables in the theoretical model that was distributed online. Besides, other variables were also added to determine the profile of the respondents. The questionnaire was divided into two parts. The first part consisted of several questions related to the profile of the respondents, such as gender, age, education, experience in the use of Blended Learning, the name of the institution, and the field of non-formal education. The second part consisted of some questions related to the variables in the theoretical model. Respondents in this research are the learners enrolled in non-formal education both Community Learning Center (PKBM) and Courses and Training Center (LKP) in Indonesia. The age of the respondents were at least 17 years and had been using Blended Learning at least for a month.

The number of the population of learners in non-formal education institutions is not known, but certainly more than 100,000. Therefore, with a precision target of 5 percent and a confidence level of 95 percent, the minimum number of learners required was 400 respondents. Data were collected by using the purposive (judgmental) sampling method, which is suitable to use in collecting data from respondents with certain characteristics [36]. Fit statistic is to assess the extent of the characteristic values of the model, which are determined using the estimated parameters and the structure of the model according to the characteristic values estimated from the sample data [37]. The selection of non-formal education is considered to represent the lifestyle of the millennial generation that is currently using the internet as a primary need. Respondents were taken from ten institutions of non-formal education in five different Districts, in which each institution was targeted 100 respondents. Communication with the educational institutions was carried out personally by the researcher with the public relations from the respective educational institutions. The implementation of the research on each of the educational institutions was carried out directly by the researcher with the help of the public relations staff of each educational institution.

The results of the questionnaire were input to SPSS worksheet, and the accuracy of the input data was checked by using the random selection of as much as $10 \%$ of the whole data. After all data was entered, the value of the outlier was identified (with the value of the standard deviation is greater than or equal to 3). Then, the data within outlier values were eliminated. Principal component factor analysis was used to test the validity (discriminant and convergent) of every indicator of all the variables in the theoretical model [38]. Meanwhile, to test the reliability of the measurement of the indicators of each

Kurniawan, Pramana, Budianto (The Adoption of Blended Learning in Non-Formal Education Using Extended Technology Acceptance Model) 
variable, the researcher used Cronbach alpha coefficients [39]. After going through the stages of data preparation above, various methods of descriptive statistics (average, standard deviation, skewness, and kurtosis) were used to analyze the data which was prepared for the variables of the theoretical model. The frequency distribution was used to analyze the respondents' answers to get an overview of the profile of the respondents' characteristics. Elimination of data with outlier value was expected to produce the distribution of the indicator values in such a way that the value of skewness and kurtosis were in the maximum limit of 3 and 7, so that the data is eligible to be used for the analysis of SEM [40]. T-test was used to compare the average values of the variables of the theoretical model with the value of neutral 3 , male and female respondents, and respondents with different experience periods of using Blended Learning. Pearson correlation coefficients were also used to study the relationships among the variables of the theoretical model.

For SEM analysis on the theoretical model, three different models of measurement were considered to use. They were Path Analysis (PA), Partially Latent Structured Regression (PLSR), and Latent Structured Regression (LSR). Each model uses the same model structure of cause and effect among variables. Nevertheless, each model uses different approaches to measure the variables. The important difference between the three models is how latent variables are treated. PA and PLSR Models are suitable for exploratory study, while the LSR model is suitable for the study of confirmatory [41]. In this study, LSR was selected as the measurement model that supported the measurement of latent variables through direct measurements on all the indicators. SEM analysis was conducted using AMOS software and followed the guidelines from [40].

\section{Results and Discussion}

\subsection{Data Preparation}

After gathering 607 responses, the data was then input to SPSS Version 19. Forty-one (41) of the questionnaires were found to enter at least one value of outliers to the model variables, and the questionnaires were removed from the sample to provide a valid final sample size which was 566, which meets the minimum sample size of 400 for the research aforementioned.

Factor analysis of the main components was used to test the construct validity (discriminant and convergent) of size eight latent variable models. Table 2 shows the final results of the factor analysis in which each indicator has a loading factor with a size of the least 0,4 only on the latent variables associated with the eigenvalues of at least 1 [38].

Table 2. Validity Analysis

\begin{tabular}{|c|c|c|c|c|c|c|c|c|}
\hline \multirow[b]{2}{*}{ Indicators } & \multicolumn{8}{|c|}{ Latent Variables } \\
\hline & $\begin{array}{l}\text { Behavioral } \\
\text { Intention }\end{array}$ & $\begin{array}{c}\text { Self- } \\
\text { Efficacy }\end{array}$ & $\begin{array}{c}\text { Social } \\
\text { Influence }\end{array}$ & $\begin{array}{l}\text { Perceived } \\
\text { Ease of Use }\end{array}$ & $\begin{array}{l}\text { Perceived } \\
\text { Usefulness }\end{array}$ & $\begin{array}{l}\text { Computer } \\
\text { Experience }\end{array}$ & $\begin{array}{c}\text { System } \\
\text { Functionality }\end{array}$ & $\begin{array}{c}\text { System } \\
\text { Interactivity }\end{array}$ \\
\hline BI1 & .880 & & & & & & & \\
\hline BI4 & .877 & & & & & & & \\
\hline BI2 & .871 & & & & & & & \\
\hline BI3 & .869 & & & & & & & \\
\hline SE3 & & .868 & & & & & & \\
\hline SE1 & & .867 & & & & & & \\
\hline SE4 & & .865 & & & & & & \\
\hline SE2 & & .858 & & & & & & \\
\hline SIC3 & & & .906 & & & & & \\
\hline SIC2 & & & .898 & & & & & \\
\hline SIC1 & & & .896 & & & & & \\
\hline PEU2 & & & & .920 & & & & \\
\hline PEU1 & & & & .905 & & & & \\
\hline PEU3 & & & & .900 & & & & \\
\hline PU1 & & & & & .909 & & & \\
\hline PU2 & & & & & .906 & & & \\
\hline
\end{tabular}

Kurniawan, Pramana, Budianto (The Adoption of Blended Learning in Non-Formal Education Using Extended Technology Acceptance Model) 


\begin{tabular}{|c|c|c|c|c|c|c|c|c|}
\hline \multirow[b]{2}{*}{ Indicators } & \multicolumn{8}{|c|}{ Latent Variables } \\
\hline & $\begin{array}{l}\text { Behavioral } \\
\text { Intention }\end{array}$ & $\begin{array}{l}\text { Self- } \\
\text { Efficacy }\end{array}$ & $\begin{array}{c}\text { Social } \\
\text { Influence }\end{array}$ & $\begin{array}{l}\text { Perceived } \\
\text { Ease of Use }\end{array}$ & $\begin{array}{l}\text { Perceived } \\
\text { Usefulness }\end{array}$ & $\begin{array}{l}\text { Computer } \\
\text { Experience }\end{array}$ & $\begin{array}{c}\text { System } \\
\text { Functionality }\end{array}$ & $\begin{array}{c}\text { System } \\
\text { Interactivity }\end{array}$ \\
\hline PU3 & & & & & .899 & & & \\
\hline CE1 & & & & & & .904 & & \\
\hline CE2 & & & & & & .902 & & \\
\hline CE3 & & & & & & .885 & & \\
\hline SF1 & & & & & & & .883 & \\
\hline SF3 & & & & & & & .877 & \\
\hline SF2 & & & & & & & .877 & \\
\hline SI3 & & & & & & & & .863 \\
\hline SI1 & & & & & & & & .858 \\
\hline SI2 & & & & & & & & .857 \\
\hline
\end{tabular}

In the process of determining the construct validity of the size of the latent variables, it was found that each indicator was loaded significantly. It is a common result as described by Davis, Bagozzi, \& Warshaw [42].

Reliability equivalence (internal consistency) of the valid indicators generated from the final factor analysis was tested using the coefficient of Cronbach Alpha. The results are shown in Table 3, which is the interpretation of George \& Mallery [39].

Table 3. The Analysis of the Reliability

\begin{tabular}{|c|c|c|c|}
\hline Latent Variables & Indicators & Alpha & Interpretation \\
\hline System Functionality & SF $(1,2,3)$ & $\mathbf{. 9 0 1}$ & Excellent \\
\hline System Interactivity & SI $(1,2,3)$ & $\mathbf{. 8 9 7}$ & Good \\
\hline Self-Efficacy & SE $(1,2,3,4)$ & $\mathbf{. 9 2 0}$ & Excellent \\
\hline Computer Experience & CE $(1,2,3)$ & $\mathbf{. 9 2 9}$ & Excellent \\
\hline Social Influence & SIC $(1,2,3)$ & $\mathbf{. 9 4 5}$ & Excellent \\
\hline Perceived Usefulness & PU $(1,2,3)$ & $\mathbf{. 9 4 1}$ & Excellent \\
\hline Perceived Ease of Use & PEU $(1,2,3)$ & $\mathbf{. 9 4 0}$ & Excellent \\
\hline Behavioral Intention & BI $(1,2,3,4)$ & $\mathbf{. 9 2 7}$ & Excellent \\
\hline
\end{tabular}

From Table 3, it is shown that the reliability equivalence of the size of the latent variables has the interpretation of at least "Good", while the others are Very Good, and it can be concluded that the proposed research model is valid and reliable.

\subsection{Descriptive Analysis}

Table 3 displays the descriptive statistics for each model variable in the theoretical model (Figure 1). In Table 4, in addition to statistics for each of the indicators for the latent variables, latent variables had been reduced to single-scale intervals. Variable with a value calculated for each respondent is the average of the values given in the indicator. For example, for each respondent, the size of a single interval scale on Perceived Ease of Use was calculated as (PEU1 + PEU2 + PEU3) / 3. The measurement of the single interval scale of the latent variables used in the descriptive analysis is presented in this section.

Table 4. Descriptive Statistics

\begin{tabular}{|c|c|c|c|c|c|c|}
\hline Variable & Min. & Max. & Mean & $\begin{array}{l}\text { Standard } \\
\text { Deviation }\end{array}$ & Skewness & Kurtosis \\
\hline SF1 & 1 & 5 & 3,52 & 1,090 & $-0,705$ & $-0,018$ \\
\hline SF2 & 1 & 5 & 3,63 & 1,102 & $-0,721$ & $-0,071$ \\
\hline SF3 & 1 & 5 & 3,57 & 1,122 & $-0,727$ & $-0,068$ \\
\hline
\end{tabular}




\begin{tabular}{|c|c|c|c|c|c|c|}
\hline Variable & Min. & Max. & Mean & $\begin{array}{l}\text { Standard } \\
\text { Deviation }\end{array}$ & Skewness & Kurtosis \\
\hline System Functionality & 1,00 & 5,00 & 3,5736 & 1,00948 & $-0,935$ & 0,164 \\
\hline SI1 & 1 & 5 & 3,49 & 1,127 & $-0,471$ & $-0,430$ \\
\hline SI2 & 1 & 5 & 3,41 & 1,130 & $-0,427$ & $-0,541$ \\
\hline SI3 & 1 & 5 & 3,42 & 1,134 & $-0,502$ & $-0,461$ \\
\hline System Interactivity & 1,00 & 5,00 & 3,4435 & 1,02929 & $-0,644$ & $-0,439$ \\
\hline SE1 & 1 & 5 & 3,58 & ,998 & $-0,597$ & $-0,022$ \\
\hline SE2 & 1 & 5 & 3,43 & 1,041 & $-0,561$ & $-0,100$ \\
\hline SE3 & 1 & 5 & 3,55 & 1,113 & $-0,721$ & $-0,099$ \\
\hline SE4 & 1 & 5 & 3,51 & 1,018 & $-0,513$ & $-0,160$ \\
\hline Self-Efficacy & 1,00 & 5,00 & 3,5181 & ,93660 & $-0,769$ & $-0,064$ \\
\hline CE1 & 1 & 5 & 3,31 & 1,130 & $-0,256$ & $-0,594$ \\
\hline CE2 & 1 & 5 & 3,33 & 1,143 & $-0,493$ & $-0,506$ \\
\hline CE3 & 1 & 5 & 3,39 & 1,136 & $-0,616$ & $-0,279$ \\
\hline Computer Experience & 1,00 & 5,00 & 3,3433 & 1,06306 & $-0,558$ & $-0,464$ \\
\hline SIC1 & 1 & 5 & 3,42 & 1,190 & $-0,577$ & $-0,412$ \\
\hline SIC2 & 1 & 5 & 3,42 & 1,140 & $-0,451$ & $-0,461$ \\
\hline SIC3 & 1 & 5 & 3,37 & 1,126 & $-0,539$ & $-0,313$ \\
\hline Social Influence & 1,00 & 5,00 & 3,4034 & 1,09347 & $-0,616$ & $-0,380$ \\
\hline PU1 & 1 & 5 & 3,54 & 1,151 & $-0,687$ & $-0,204$ \\
\hline PU2 & 1 & 5 & 3,51 & 1,155 & $-0,623$ & $-0,276$ \\
\hline PU3 & 1 & 5 & 3,53 & 1,156 & $-0,734$ & $-0,111$ \\
\hline Perceived Usefulness & 1,00 & 5,00 & 3,5277 & 1,09181 & $-0,830$ & $-0,077$ \\
\hline PEU1 & 1 & 5 & 3,56 & 1,145 & $-0,721$ & $-0,150$ \\
\hline PEU2 & 1 & 5 & 3,54 & 1,091 & $-0,749$ & $-0,063$ \\
\hline PEU3 & 1 & 5 & 3,53 & 1,128 & $-0,723$ & $-0,071$ \\
\hline Perceived Ease of Use & 1,00 & 5,00 & 3,5442 & 1,06038 & $-0,872$ & $-0,077$ \\
\hline BI1 & 1 & 5 & 3,63 & 1,071 & $-0,789$ & 0,157 \\
\hline $\mathrm{BI} 2$ & 1 & 5 & 3,66 & 1,001 & $-0,576$ & $-0,058$ \\
\hline $\mathrm{BI} 3$ & 1 & 5 & 3,57 & 0,989 & $-0,672$ & 0,165 \\
\hline $\mathrm{BI} 4$ & 1 & 5 & 3,52 & 0,993 & $-0,493$ & $-0,109$ \\
\hline Behavioral Intention & 1,00 & 5,00 & 3,5936 & 0,91850 & $-0,888$ & 0,109 \\
\hline
\end{tabular}

From Table 4, it is shown that the values of skewness and kurtosis, respectively, are within the limits of 3 and 7. This justifies the use of maximum likelihood estimation in the analysis of SEM [33]. From the results of the table of descriptive statistics, it can be concluded that:

(a) The average value of each latent variable is significantly greater than the value of the neutral 3 ( $\mathrm{p}$ $<0,05)$, which indicates that all variables are considered necessary for blended learning;

(b) Behavioral Intention has the highest average in value. Thus the interest in behavior determines the success in using blended learning. The second determining factor is System Functionality, which means the function of the application system should have more benefits in line with the wish/interest of the user of blended learning.

(c) The sample data of the respondents are worth using because the result of descriptive statistics has met the criteria determined under the references [33]. 


\subsection{Model Analysis}

SEM analysis of the theoretical model in Figure 1 was presented first and followed by the final model. The theoretical model that had been analyzed and Figure 2 show the results of the SEM analysis of the direct effects. In Figure 2 and all the following sections in this chapter, the following notation is used for all effects: the non-standard effect is indicated and followed by the symbol *,**, or *** if the effect is statistically significant at the level of $0.05,0.01$, or 0.001 , and NS (Non-Significant) shows that the nonstandard effect is not statistically significant at the level of 0.05 or less.

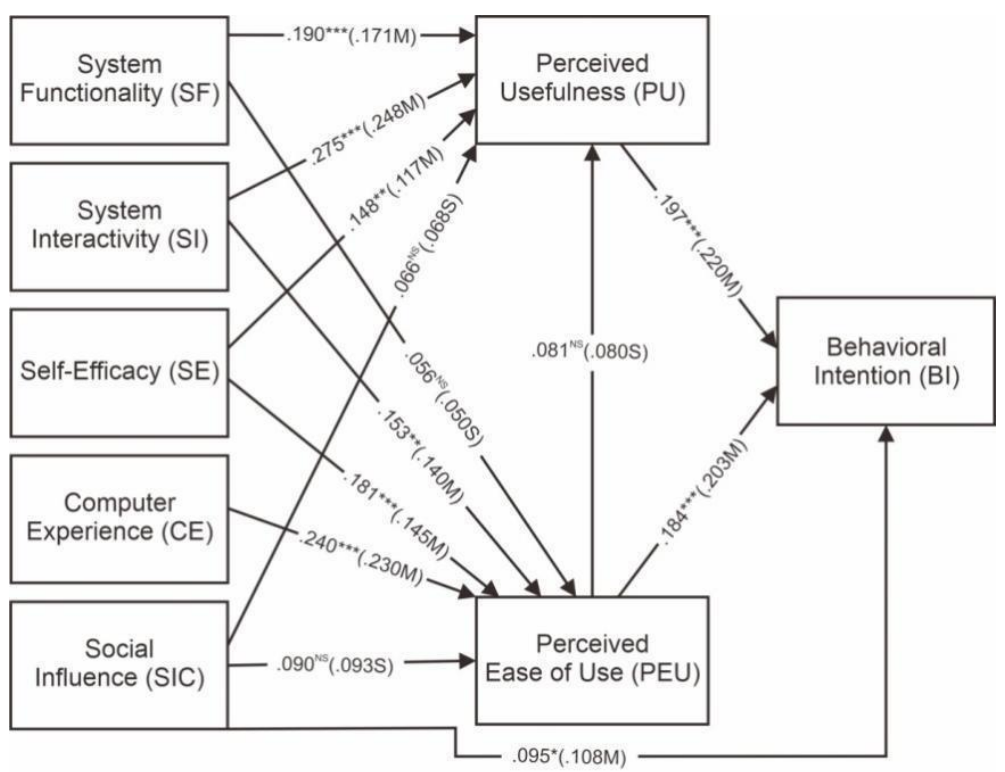

Figure 2. SEM analysis of the Theoretical Model

In Figure 2, it can be seen that there are four highlighted causal effects which are not significant statistically, they are System Functionality (SF) to Perceived Ease of Use (PEU), Social Influence (SIC) to Perceived Usefulness (PU), Social Influence (SIC) to Perceived Ease of Use (PEU) and Perceived Ease of Use (PEU) to Perceived Usefulness (PU). All other direct effects are statistically significant at the level of 0.01 or less with the size of medium or small.

Table 5. Statistical Data for The Theoretical Models

\begin{tabular}{ccccc}
\hline Indicators & Estimate & S.E & C.R & P \\
\hline SI $\rightarrow$ PEU & 0,153 & 0,054 & 2,832 & 0,005 \\
SF $\rightarrow$ PEU & 0,056 & 0,051 & 1,084 & 0,278 \\
SE $\rightarrow$ PEU & 0,181 & 0,057 & 3,178 & 0,001 \\
CE $\rightarrow$ PEU & 0,240 & 0,047 & 5,057 & $* * *$ \\
SIC $\rightarrow$ PEU & 0,090 & 0,047 & 1,933 & 0,053 \\
SF $\rightarrow$ PU & 0,190 & 0,051 & 3,686 & $* * *$ \\
SI $\rightarrow$ PU & 0,275 & 0,054 & 5,085 & $* * *$ \\
SE $\rightarrow$ PU & 0,148 & 0,057 & 2,584 & 0,010 \\
SIC $\rightarrow$ PU & 0,066 & 0,047 & 1,429 & 0,153 \\
PEU $\rightarrow$ PU & 0,081 & 0,045 & 1,812 & 0,070 \\
SIC $\rightarrow$ BI & 0,095 & 0,040 & 2,390 & 0,017 \\
PU $\rightarrow$ BI & 0,197 & 0,040 & 4,882 & $* * *$ \\
PEU $\rightarrow$ BI & 0,184 & 0,041 & 4,518 & $* * *$
\end{tabular}


From Table 5, it is shown that the statistics of fit are quite satisfactory, although four causal effects are not significant. Thus, among 13 hypotheses, there are nine hypotheses from the results of the analysis which have significant results.

Table 6. Regression of Statistical Standard for the final model

\begin{tabular}{cc}
\hline Indicators & Estimate \\
\hline SI $\rightarrow$ PEU & 0,14 \\
SF $\rightarrow$ PEU & 0,05 \\
SE $\rightarrow$ PEU & 0,145 \\
$\mathrm{CE} \rightarrow$ PEU & 0,23 \\
SIC $\rightarrow$ PEU & 0,093 \\
SF $\rightarrow$ PU & 0,171 \\
SI $\rightarrow$ PU & 0,248 \\
SE $\rightarrow$ PU & 0,117 \\
SIC $\rightarrow$ PU & 0,068 \\
PEU $\rightarrow$ PU & 0,08 \\
SIC $\rightarrow$ BI & 0,108 \\
PU $\rightarrow$ BI & 0,22 \\
PEU $\rightarrow$ BI & 0,203 \\
\hline
\end{tabular}

Table 6 gives an overview of the size/scale of the effect of each indicator in Figure 2 as described by Cohen [43] about the scale/value of the effect, which is: The standard coefficient with an absolute value less than or equal to 0.1 can show the effect of "small" (S), the absolute value between 0.1 and 0.5 is the effect of "typical" or "medium" (M), and the effect of "large" (L) may be indicated by a coefficient with a value that is greater than or equal to 0.5 .

Table 7 presents the Goodness-of-Fit statistic related to the analysis of the SEM analysis of the Theoretical Model in figure 2.

Table 7. Goodness-of-Fit Statistic for the Final Model

\begin{tabular}{|c|c|c|c|c|c|c|c|c|}
\hline $\mathbf{N}$ & $\mathbf{N C}\left(\chi^{\mathbf{2}} / \mathbf{d f}\right)$ & RMR & GFI & AGFI & NFI & IFI & CFI & RMSEA \\
\hline \multirow{2}{*}{566} & $437.338 / 276=1.585$ & .043 & .945 & .930 & .965 & .987 & .987 & .032 \\
\cline { 2 - 8 } & \multicolumn{8}{|c|}{$\mathrm{R}^{2}:$ PEU (.206), PU (.224), BI (.150) } \\
\hline
\end{tabular}

Table 7 shows that the fit statistics have good values, and it can be concluded that the data collected from the questionnaires is suitable or appropriate for the research model (Figure 1).

\subsection{Discussion Of Findings}

From the results obtained in this study, it is found that there are some different findings from the previous studies. Based on the research of Padilla-Mendez, et al. [9], there was only one exogenous variable which was the Perceived Playfulness. The research focused on addressing the emphasis of the role of pleasure perceived and introducing the gender perspective even though some studies did not find the correlation between gender and any model variable [44]. Although it used the TAM model as a tool to measure the acceptance of technology, it had a different result. The other result can be seen in the study conducted by Bachtiar, et al. [10], who did not focus on non-formal education but on a college or university in which the majority of the respondents were college students with relatively similar age and education.

After knowing the results, the researcher can summarize some actions that are suggested to support this research. There were nine indicators indicated as Medium, which also had significant results, such as 
System Functionality (SF), System Interactivity (SI), Self-Efficacy (SE), Computer Experience (CE), Social Influence (SI). System Interactivity (SI) had a very significant influence on Perceived Usefulness (PU). The action that needs to be done is the implementation of the application used by the learners to have real interactions that can be perceived by the user, such as the students use a system that is already provided by the institution which can be used and utilized well. Thus the learners will automatically like and be happy with what they are using. On the other hand, several studies dis not show significant results of the data analysis process because the variables were not fully affecting the use of blended learning in the institutions. In addition, social influence which was supposed to affect the implementation of blended learning massively showed the contrary result. In the future, it can be the focus for further research.

In Figure 2, it is also shown that four indicators were not significant in this study, such as the Social Influence (SIC) exogenous variable. SIC had a non-significant value and small size/scale towards the Perceived Usefulness (PU) and Perceived Ease of Use (PEU). So, the suggestions for further research is to look for the causes or to eliminate the variable of Social Influence (SIC) in similar studies to this study.

The Four Variables which are the System Functionality (SF), System Interactivity (SI), SelfEfficacy (SE), Computer Experience (CE) are significant towards the Basic Variables of the Technology Acceptance Model (TAM) and worthy enough to be followed up by actions such as face-to-face and online learning which should have functional system and systems that have interactions both on the usability perceived and the ease in attending the learning process. There are two variables on learners that have significant effects: self-confidence that needs to be improved by learners by providing directions or guidelines which have usefulness or benefits objective, and the ease perceived by the students using Blended Learning in non-formal education.

The last variable with significant value is Computer Experience (CE) towards the Perceived Ease of Use (PEU). It shows that it is necessary to perform habituation for learners to use computer or for educators to socialize the habituation, so that learners will have positive experiences and feel the ease of having Blended Learning. The results show that ten previous studies had similar results to this study such as [10][17][13][11][14][16][18][19][12][15]. However, not all previous studies had significant results in the context of this case study.

Four hypotheses were not significant, which had inversely proportional results to the research ever conducted on blended learning, such as System Functionality which was not significant towards Perceived Ease of Use. Meanwhile, there were significant results between the System Functionality with Perceived Ease of Use as seen in other studies [10][13]. Unlike the previous studies, this study shows that System Functionality variable has no significant effects on the ease of use. So, it is reasonable if it provides different results and is not similar. The researcher concludes that, in general, research on the adoption of Blended Learning in non-formal education by using the extended Technology Acceptance Model is not fully significant or partially supports the majority of the findings in previous studies.

The results of this study have managerial implications that can be used by the managers of the course institutions to improve the quality of the course institutions they lead. For example, the manager of the institution can ensure that the application used by learners must have complete learning features, such as downloading materials, answering quizzes, storing and replaying learning videos (system functionality). To support the Support Interactivity, the manager is obliged to provide features in the application in which students can give feedback during online learning activities, do interactive quizzes, discuss with other learners, and communicate learners and teachers.

\section{Conclusion}

The conclusion of this research is nine factors determined the result of the acceptance of students receiving the Adoption of Blended Learning. The determinant factors showing significant relations with Medium values are: 
- System Functionality (SF), System Interactivity (SI), and Self-Efficacy (SE) had significant effects on Perceived Usefulness (PU);

- System Interactivity (SI), Self-Efficacy (SE), and Computer Experience (CE) were significant to Perceived Ease of Use (PEU),

- Social Influence (SIC) had significant effects on Behavioral Intention (BI)

- Perceived Usefulness (PU) had significant effects on Behavioral Intention (BI)

- Perceived Ease to Use (PEU) had both positive and significant direct effects on Behavioral Intention (BI).

System Interactivity (SI) had the highest value and was followed by the Computer Experience (CE) as the second. Four determinant factors were not significant or had small values; they were System Functionality (SF) towards the Perceived Ease of Use (PEU), Social Influence (SIC) towards the Perceived Usefulness (PU), Social Influence (SIC) towards the Perceived Ease of Use (PEU) and Perceived Ease of Use (PEU) towards the Perceived Usefulness (PU) which had small values below .090. Thus, the result found in this study is that in the adoption of Blended Learning in non-formal education, not all factors had significant values.

From the results obtained, there are several limitations in this study that have not been studied further by the researcher. For example, the respondents were only in Java, whereas there are five large islands in Indonesia and thousands of islands in Indonesia. It is suggested for other researchers to reproduce the study using samples from non-formal education institutions in other Indonesian territories. Furthermore, the exogenous variables used in this study were only five, so there is a great possibility to use more variables. Different values will possibly be generated.

For further studies, this study opens more possibility of research on a comparison between students of a rural and urban area, studies on different learning groups, studies which allow comparison on the level of last education, comparison on the efficiency between theory and practice in non-formal education, and studies that incorporate the characteristics of the course institutions with a specific culture of Indonesian people. Thus, further research will have positive values and can also be used as references for future similar studies.

\section{References}

[1] Latchem, C. (2018). Open and distance non-formal education in developing countries. Singapore: Springer.

[2] Mulwa, C., Lawless, S., Sharp, M., Arnedillo-Sanchez, I., \& Wade, V. (2010, October). Adaptive educational hypermedia systems in technology enhanced learning: a literature review. In Proceedings of the 2010 ACM conference on Information technology education (pp. 73-84). ACM. https://doi.org/10.1145/1867651.1867672

[3] Leow, F. T., \& Neo, M. (2015). Redesigning the classroom environment to enhance students' collaborative learning activities. In Emerging Issues in Smart Learning (pp. 267- 274). Springer Berlin Heidelberg.

[4] Lim, Ab Jalil, Ma'rof, \& Saad (2020). Peer Learning, Self-Regulated Learning and Academic Achievement in Blended Learning Courses, A SEM Approach, iJET - Vol. 15, No. 3, 2020. https://doi.org/10.3991/ijet.v15i03.12031.

[5] Wu, J.-H., Tennyson, R. D., \& Hsia, T.-L. (2010). A study of student satisfaction in a blended elearning system environment. Computers \& Education, 55(1), 155-164.

[6] Tayebinik, M., \& Puteh, M. (2013). Blended Learning or E-learning? arXiv preprint arXiv:1306.4085.

[7] Vo, H. M., Zhu, C., \& Diep, N. A. (2017). The effect of blended learning on student performance at course-level in higher education: A meta-analysis. Studies in Educational Evaluation, 53, 17-28. 
[8] Dakduk, Banderali \& Woude (2018). Acceptance of Blended Learning in Executive Education. SAGE Open, July-September 2018: 1-16. DOI: 10.1177/2158244018800647.

[9] Antonio Padilla-Melendez, Ana Rosa del Aguila-Obra, Aurora Garrido-Moreno. (2012). Perceived playfulness, gender differences and technology acceptance model in a blended learning scenario. Computer \& Education.

[10] Fitra A. Bachtiar, Aditya Rachmadi, anda Fajar Pradana. (2014). Acceptance in the Deployment of Blended Learning as a learning Resource in Information Technology and Computer Science Program, Brawijaya University. -Pacific Conference on Computer Aided System Engineering.

[11] Mohamed Yeou. (2016). An Investigation of Students' Acceptance of Moodle in a Blended Learning Setting Using Technology Acceptance Model. Journal of Educational Technology. Vol. 44(3) 300-318.

[12] Tsui-Fen Chang, Cheng-Min Chao and Bor-Wen Cheng. (2015). Framework and Verification of a Blended E-Learning System Behavioral Intention Model Among Clinical Nurses. Journal of Baltic Science Education.

[13] Khanh Ngo Nhu Tran. (2016). The Adoption of Blended E-learning Technology in Vietnam using a Revision of the Technology Acceptance Model. Journal of Information Technology Education: Research.

[14] Jako Olivier. (2016). Blended learning in a first-year language class: Evaluating the acceptance of an interactive learning environment. Literator - Journal of Literary Criticism, Comparative Linguistics and Literary Studies. ISSN: (Online) 2219-8237.

[15] Yueh-Ying Tsai, Cheng-Min Chao, Hong-Mau Lin, and Bor-Wen Cheng. Nursing staff intentions to continuously use a blended e-learning system from an integrative perspective. Springer Science and Business Media. Qual Quant 52, 2495-2513 (2018).

[16] A. 1-Azawei, P. Parslow, and K. Lundqvist. (2017) "Investigating the effect of learning styles in a blended e-learning system: An extension of the technology acceptance model (TAM)," Australasian Journal of Educational Technology, Nov.

[17] V. Moreno, F. Cavazotte, and I. Alves, "Explaining university students' effective use of e-learning platforms: Effective use of e-learning platforms" British Journal of Educational Technology, vol. 48, no. 4, pp. 995-1009, Jun. 2017.

[18] Park, S. Y., Nam, M. W., \& Cha, S. B. (2012). University students' behavioral intention to use mobile learning: Evaluating the technology acceptance model. British journal of educational technology, 43(4), 592-605.

[19] Kamla Ali Al-Busaidi. (2012). "Learners' Perspective on Critical Factors to LMS Success in Blended Learning: An Empirical Investigation". Communications of the Association for Information Systems. Vol. 30, Article 2.

[20] Reny, Bobby \& Satria (2019). The Measurement of University Students' Intention to Use Blended Learning System through TAM and TPB at Developed and Developing Regions Lessons Learned from Taiwan and Indonesia. iJET - Vol. 15, No. 9, 2020. https://doi.org/10.3991/ijet.v15i09.11517.

[21] Cheng, Y.-M. (2011). Antecedents and consequences of e-learning acceptance. Information Systems Journal, 21(3), 269-299.

[22] Pituch, K. A., \& Lee, Y. (2006). The influence of system characteristics on e-learning use. Computers \& Education, 47(2), 222-244.

[23] Abbad, M. M., Morris, D., \& De Nahlik, C. (2009). Looking under the Bonnet: Factors Affecting Student Adoption of E-Learning Systems in Jordan. The International Review of Research in Open and Distributed Learning, 10(2).

[24] Fred D. Davis, Richard P. Bagozzi and Paul R. Warshaw. (1989) User Acceptance of Computer Technology: A Comparison of Two Theoretical Models. Management Science Vol. 35 No. 8 August 1989. 
[25] A. Bandura, "Self-Efficacy: Toward a Unifying Theory of Behavioral Change*," Pergamon Press Ltd, 1978.

[26] Brown, I. Jr., \& Inouye, D.K. (1978). Learned helplessness through modeling: The role of perceived similarity in competence. Journal of Personality and Social Psychology, 36(8), 900-908.

[27] A. Koohang, The Effects of Age, Gender, College Status, and Computer Experience on Attitudes toward the Library Computer System, Library and Information Science Research, 84, pp. 349-355, 1986

[28] M. Chen, Gender and Computers: The Beneficial Effects of Experience on Attitudes, Journal of Educational Computer Research, 2:3, pp. 265-282, 1986.

[29] M. C. Linn, Fostering Equitable Consequences from Computer Learning Environments, Sex Roles, 13:3/4, pp. 229-240, 1985.

[30] Rashotte, L. (2007). Social Influence. The Blackwell Encyclopedia of Sociology.doi:10.1002/9781405165518.wbeoss 154.

[31] Robert B. Cialdini and Noah J. Goldstein. (2004). SOCIAL INFLUENCE: Compliance and Conformity. Department of Psychology, Arizona State University. Annu. Rev. Psychol. 2004. 55:591-621.

[32] Raven, B. H. (1964). Social Influence and Power. California Univ Los Angeles.

[33] Kline, R.B., (2005). "Principles and Practice of Structural Equation Modeling", Guilford Press, London.

[34] Venkatesh, V., Morris, M. G., Davis, G. B., \& Davis, F. (2003). User acceptance of information technology: Toward a unified view. Management Information System Quarterly, 27(3), 425-478. https://doi.org/10.2307/30036540

[35] Ajzen, "Theory of Planned Behavior," Organ. Behav. Hum. Decis. Process., vol. 50, pp. 179-211, 1991.

[36] W. L. Neuman, Social research methods, qualitative and quantitative approaches. Boston: Allyn and Bacon, 2006.

[37] Pramana, E. (2018). Determinants of the adoption of mobile learning systems among university students in Indonesia. Journal of Information Technology Education: Research, 17, 365-398. https://doi.org/10.28945/4119.

[38] D. Straub, M.-C. Boudreau, and D. Gefen, "Validation Guidelines for IS Positivist Research," Commun. Assoc. Inf. Syst., vol. 13, no. March, pp. 380-427, 2004.

[39] D. George and P. Mallery, SPSS for windows step by step: A simple guide and reference. 11.0 update. Boston: Allyn and Bacon, 2003.

[40] R. B. Kline, Principles and practice of structural equation modeling, 4th ed. London: Guilford Press, 2016.

[41] R. E. Schumacker and R. G. Lomax, A beginner's guide to structural equation modeling, 4th ed. New York: Routledge, 2016.

[42] Davis, F., Bagozzi, R., \& Warshaw, P., (1992). "Extrinsic and Intrinsic Motivation to Use Computers in the Workplace”, Journal of Applied Social Psychology, 22(14):1111-2132.

[43] Cohen, J. (1988). "Statistical Power Analysis for the Behavioral Sciences (2nd ed.)", Academic Press, New York.

[44] Hind Abdulaziz Alfadda \& Hassan Saleh Mahdi (2020). Measuring Students' Use of Zoom Application in Language Course Based on the Technology Acceptance Model (TAM). https://doi.org/10.1007/s10936-020-09752-1 